* Corresponding author

Phone +421556022466

E-mail address: patrik.sarga@tuke.sk (P. Šarga)

Article information

Article history: AMS-Volume15-No.1-00103-11

Received 23 March 2011

Accepted 26 May 2011

Available online 26 August

\section{Using of Program MEZVYNA for Measurement of Residual Stresses to Solving Practical Problems}

\author{
František Trebuňa a ${ }^{a}$ Patrik Šarga a* \\ a Department of Applied Mechanics and Mechatronics, Faculty of Mechanical Engineering, Letná 9, 04200 Košice, Slovak Republic
}

\section{BIOGRAPHICAL NOTES}

František Trebuňa, Dr.h.c. mult. Prof. Ing. CSc. is a professor of applied mechanics, Dean of Faculty of Mechanical Engineering of Technical university of košice, Head of the Department of Applied Mechanics and Mechatronics. He is author of 9 monographs, 9 university textbook, special book publications, 12 university notebooks and more than 300 publications in journals and conference proceedings at Slovakia abroad. He is author of important projects and engineering works. He received several prizes at home and abroad. He received three honorary Doctor Honoris Causa (Dr.h.c.) including two from foreign universities for the development of applied mechanics and mechatronics.

Patrik Šarga, Ing. PhD. (born in 1979) he graduated in "Automation and Control in Mechanical Engineering" at Technical University of Košice in 2002. He was an internal PhD. student at the Department of Applied Mechanics and Mechatronics and in 2005 he defended his dissertation thesis in field of mechatronics. Nowadays he works as an assistant on the Department of Applied Mechanics and Mechatronics at the Faculty of Mechanical Engineering at Technical University of Košice. He is co-author of one book of lecture notes and more than 50 publications in journals and conference proceedings at Slovakia and abroad, e.g. Engineering Failure Analysis, Metalurgija. He has worked on several grant projects, research tasks and many projects solved for industry realized on the department.

\section{KEY WORDS}

Residual Stress, Hole-Drilling, Strain Gage

\section{ABSTRACT}

The hole-drilling method has wide application in solving of various tasks resulting from practice. On the Department of Applied Mechanics and Mechatronics of Technical university of Košice were solved many problems on the basis of contracts on which we could verify our theoretical knowledge from the area of determination of residual stresses. The paper is devoted to using of program MEZVYNA (Šarga, 2005) to determination of residual stresses by the hole-drilling method. The program was developed on the above-mentioned department.

\section{Introduction}

On our workplace was developed program MEZVYNA that serves for determination of residual stresses by the hole-drilling method (Trebuňa, Šimčák et al., 2005). The hole-drilling method is a semi destructive method due to fact that only small portion of machine part is damaged and accordingly it can be used for further operation. Pro- 
gram MEZVYNA is used for computation of residual stresses by ASTM method, method of power series and by integral method. It can be used with systems RS-200 or SINT MTS-3000.

In this paper are described only some projects for solution of which was used this program for evaluation of residual stresses. Due to occasion to cooperate on these projects it was possible to verify correctness of program and to provide adjustment of its functionality.

Depending on conditions on individual workplaces there were used for the measurement systems RS-200 and SINT MTS-3000. For the evaluation of measured data were used programs RESTRESS, RESTAN or program MEZVYNA.

\section{Expert Opinion of Stop Logs on Inlets of Hydroelectric Power Plant}

Review of stop logs (Fig. 1) after sand blasting and analysis of panel loading together with modeling by the finite element method demonstrated very serious facts about stress levels in locations of stress concentrators. Local corrosion and local plastic deformations of flange of main beam of bottom stop log invoked

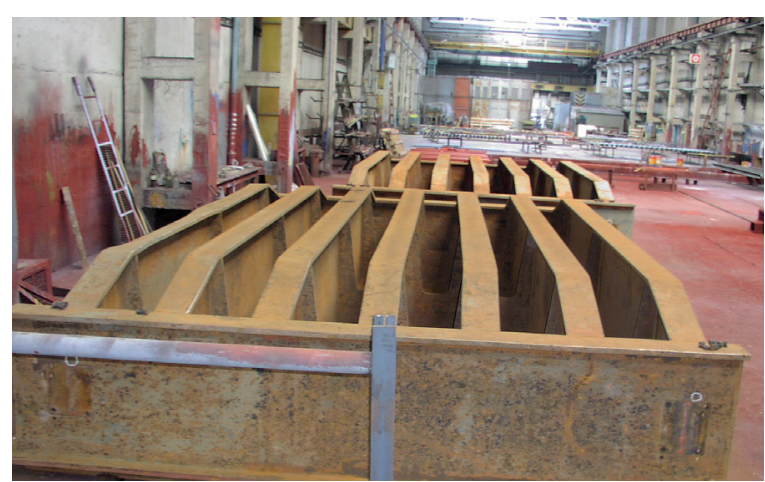

Fig. 1: Stop logs before sand blasting. a series of questions concerning reason of plastic deformation and with influence of this plastic deformation to possible stress increasing or safety of such deformed stop log (Trebuňa et al., 2004).

On the basis of contract there was realized expert opinion of stop logs of inlet in hydroelectric power plant. The contract includes quantification of stresses in location of concentrators by methods of mathematical modeling by the finite element method and quantification of residual stresses in the stop log structures according to American Standard ASTM 837-01 (ASTM Standard E837-01) measured by system SINT MTS 3000 (Fig. 2). Results from modeling and quantification of residual stresses served to determination of location of inspection points of possible failures in welds or to determination of reparation of deformed locations.

Strain-gage rosettes RY 21 were applied to stop log panel in locations and directions according to Fig.3.

Strains measured in location I are given in Tab. 1. From the measured values of strains were on the basis of Standard ASTM E837-01 determined residual stresses. In Fig. 4 is shown the record from ASTM method in location I determined by program MEZVYNA.

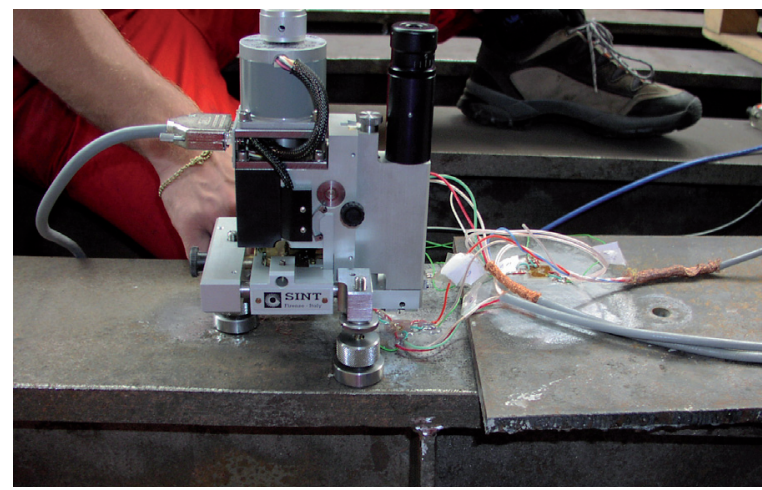

Fig. 2: Measurement system SINT MTS-3000.

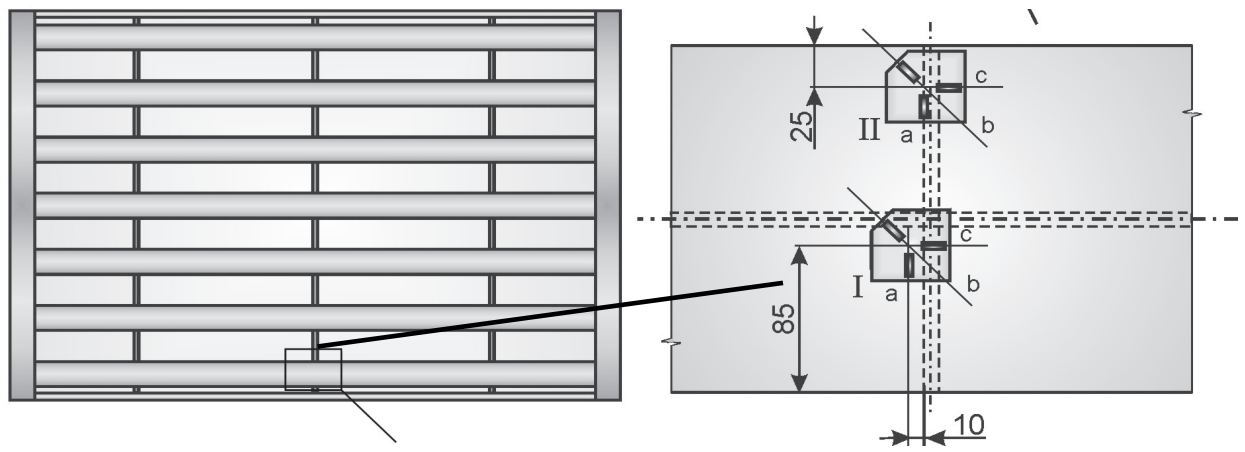

Fig. 3: Location of rosettes RY 21 on flange of fastening web of panel sheet. 
Table 1: Strains in location I.

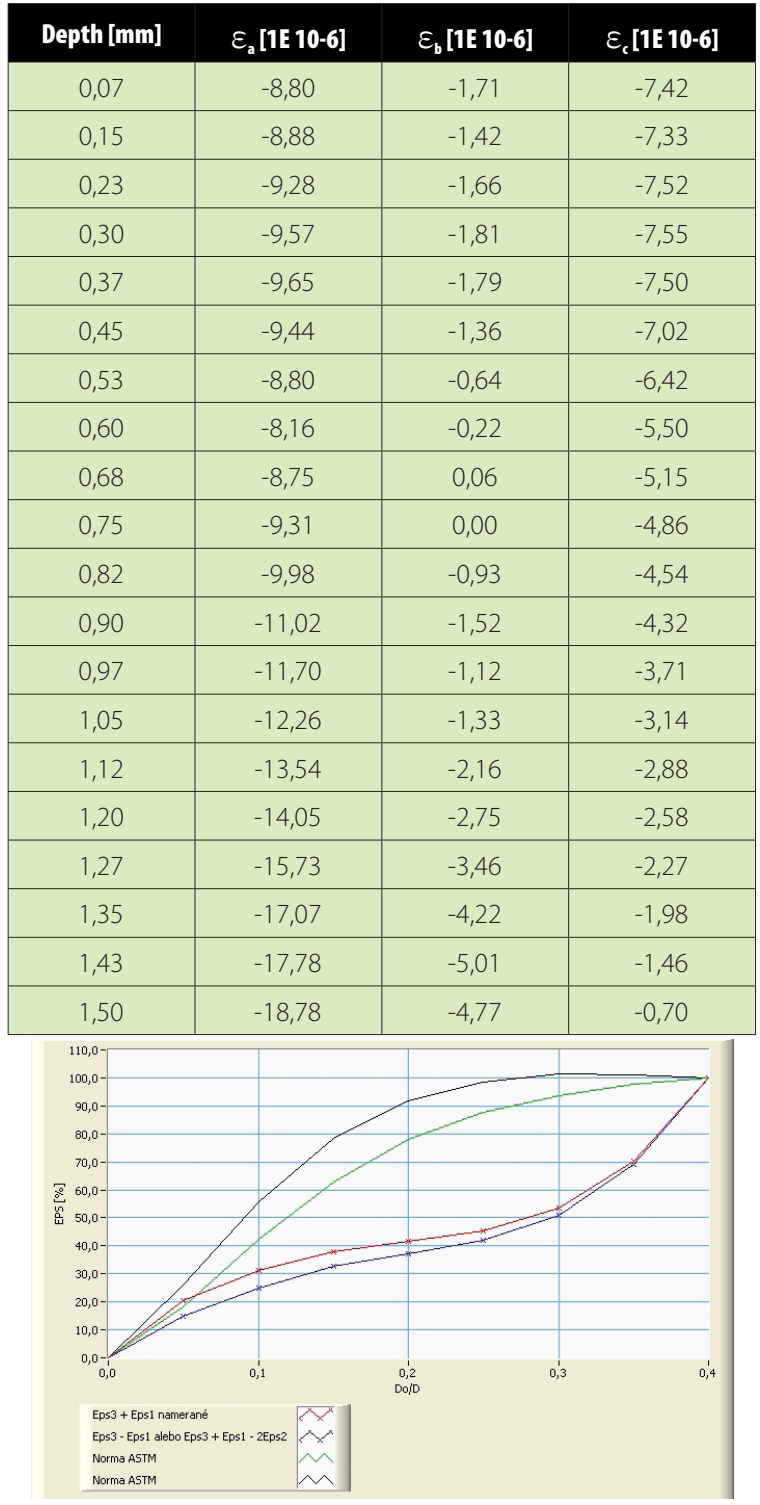

Fig. 4: Residual stresses in location I determined by ASTM method and program MEZVYNA.

\section{Determination of Residual Lifespan of Pipe Yards of Compressor Stations}

The second task that will be described in this paper is connected with determination of residual stresses in pipes by program MEZVYNA. For determination of damage accumulation is necessary to know also residual stresses in the pipe. Residual stresses can have positive or negative influence that depends on amplitude, sign, and distribution of stress with respect to stresses induced by loading.

On the basis of contract there were accomplished expert opinion concerning determination of residual lifespan of pipe yards of compressor stations (Trebuňa et al., 2004).

Significant change of residual stress distribution along thickness of pipe wall occurred after reconstruction when sanding was used for cleaning of pipe surface. The evaluation was accomplished by Standard ASTM E837-01, integral method, method of power series, and Kockelmann method. During the measurement by system RS - 200 were used straingages HBM 3/120 - RY 21 and for measurement by system MTS - 3000 SINT were applied strain-gages HBM 1,5/120 - RY 61. For the evaluation of stresses were used program products Restres and Restran as well as program MEZVYNA.

In Fig. 5 is shown positioning of measurement system SINT - MTS 3000 on the pipe specimen and in Fig. 6 is applied strain-gage RY 61 on the body of pipe.

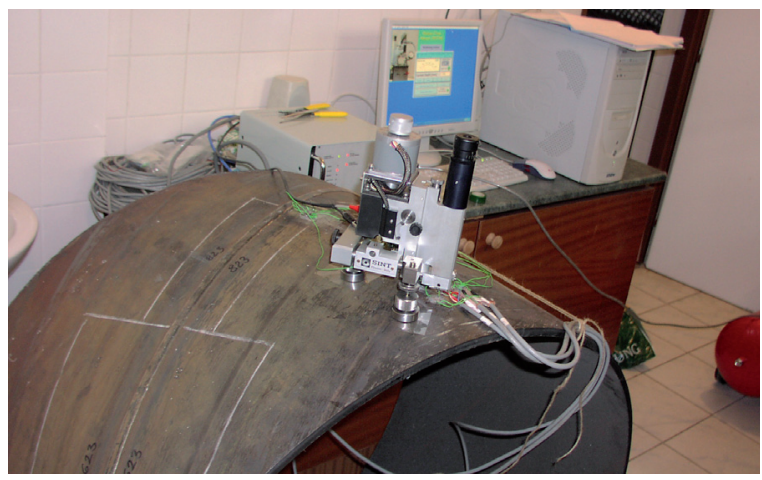

Fig. 5: Fixing of system SINT - MTS 3000

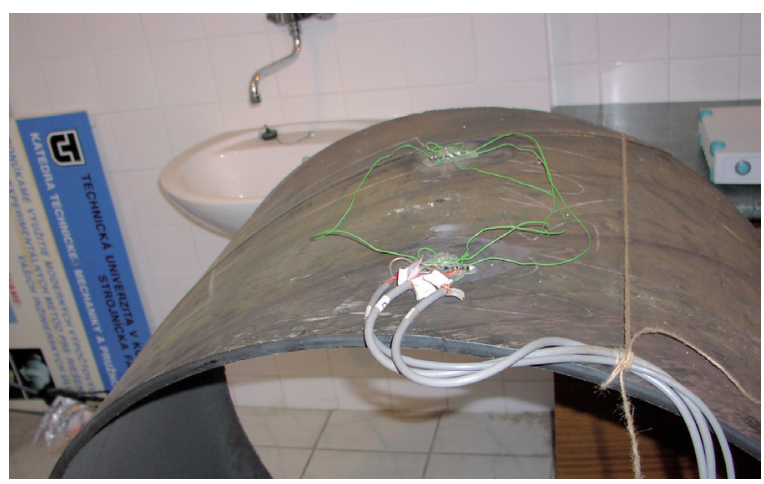

Fig. 6: Strain-gage RY 61 on the pipe.

In Tab. 2 and Fig. 7 are given results of measurements according to integral method gained by program MEZVYNA . 
Table 2: Record from measurement by integral method - computed values.

\begin{tabular}{|c|c|c|c|c|c|c|c|c|}
\hline Depth [mm] & $\varepsilon_{\mathrm{a}}[1 \mathrm{E}$ 10-6] & $\varepsilon_{b}[1 E$ 10-6] & $\varepsilon_{c}$ [1E 10-6 & $\alpha\left[{ }^{\circ}\right]$ & $\sigma_{\min }[\mathrm{N} / \mathrm{m} 2]$ & $\sigma_{\max }[\mathrm{N} / \mathrm{m} 2]$ & $\begin{array}{l}\text { Von Mises } \\
\left.\text { [N/mm }{ }^{2}\right]\end{array}$ & $\begin{array}{c}\text { Tresca } \\
{\left[\mathrm{N} / \mathrm{mm}^{2}\right]}\end{array}$ \\
\hline 0,025 & 5,962 & 0,349 & 4,02 & 50,907 & $-214,606$ & $-42,829$ & 196,719 & 171,776 \\
\hline 0,075 & 12,209 & 3,396 & 9,46 & 50,233 & $-169,209$ & $-90,564$ & 146,661 & 78,645 \\
\hline 0,125 & 19,122 & 8,866 & 16,191 & 49,733 & $-142,818$ & $-125,219$ & 134,882 & 17,599 \\
\hline 0,175 & 26,828 & 16,256 & 24,018 & 49,356 & $-154,844$ & $-127,367$ & 137,54 & 18,477 \\
\hline 0,225 & 35,287 & 25,003 & 32,716 & 49,065 & $-152,088$ & $-118,96$ & 138,527 & 33,127 \\
\hline 0,275 & 44,367 & 34,587 & 42,052 & 48,823 & $-168,921$ & $-141,445$ & 156,997 & 27,476 \\
\hline 0,325 & 53,885 & 44,583 & 51,8 & 48,596 & $-175,846$ & $-150,807$ & 164,76 & 25,04 \\
\hline 0,375 & 63,64 & 54,67 & 61,751 & 48,357 & $-173,253$ & $-157,675$ & 166,013 & 15,578 \\
\hline 0,425 & 73,443 & 64,625 & 71,721 & 48,088 & $-179,729$ & $-170,545$ & 175,318 & 9,184 \\
\hline 0,475 & 83,122 & 74,306 & 81,551 & 47,793 & $-176,009$ & $-171,274$ & 173,69 & 4,735 \\
\hline 0,525 & 92,533 & 83,627 & 91,11 & 47,481 & $-182,428$ & $-179,456$ & 180,96 & 2,972 \\
\hline 0,575 & 101,563 & 92,539 & 100,292 & 47,166 & $-190,418$ & $-186,816$ & 188,643 & 3,602 \\
\hline 0,625 & 110,129 & 101,015 & 109,017 & 46,858 & $-190,146$ & $-187,15$ & 188,666 & 2,996 \\
\hline 0,675 & 118,175 & 109,035 & 117,228 & 46,564 & $-197,198$ & $-194,414$ & 195,82 & 2,784 \\
\hline 0,725 & 125,671 & 116,582 & 124,888 & 46,289 & $-201,53$ & $-196,444$ & 199,036 & 5,087 \\
\hline 0,775 & 132,065 & 123,639 & 131,979 & 46,035 & $-205,662$ & $-198,567$ & 202,208 & 7,094 \\
\hline 0,825 & 138,982 & 130,189 & 138,501 & 45,807 & $-215,633$ & $-206,164$ & 211,058 & 9,469 \\
\hline 0,875 & 144,821 & 136,219 & 144,464 & 45,606 & $-225,366$ & $-214,476$ & 220,123 & 10,89 \\
\hline 0,925 & 150,146 & 141,724 & 149,893 & 45,436 & $-224,147$ & $-215,319$ & 219,866 & 8,828 \\
\hline 0,975 & 154,991 & 146,709 & 154,821 & 45,297 & $-239,013$ & $-231,563$ & 235,377 & 7,45 \\
\hline
\end{tabular}
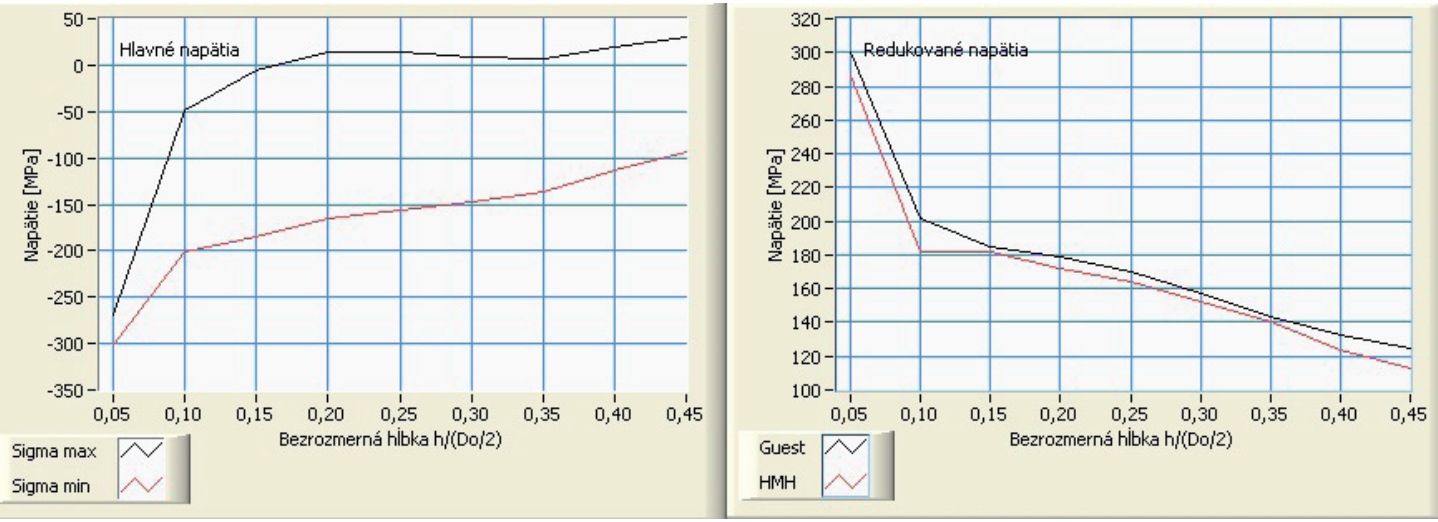

Fig. 7: Chart of residual stresses computed by integral method and chart of equivalent stresses in program MEZVYNA.

The measurements were realized by RS - 200 and the evaluation was accomplished by programs Restres, Restan and MEZVYNA.

The measurements accomplished by two different measurement systems and evaluated also by different professional program products have confirmed precondition that in pipes used for building of compressor stations are high magnitudes of residual stresses.

\section{Vibration of Converter Pedestal}

According to contract it was necessary to provide measurement of vibrations of converter pedestal (Fig.8) and consequently to propose structural changes, to re-measure and re-evaluate possible structural modifications.

It was also necessary to determine levels of residual stresses in the welded body (inn pedestal) and by method of hole-drilling to determine static levels 
of stresses due to self weight of structure, including residuals of steel on the converters vessel (Trubuña et al., 2005). For determination of residual stresses in converter pedestal were applied strain-gages RY 21 on outer vertical ribs of pedestal without drives at the height cca $900 \mathrm{~mm}$ from base plane and on plane side of rib at the distance $100 \mathrm{~mm}$ from the edge (Fig. 9).

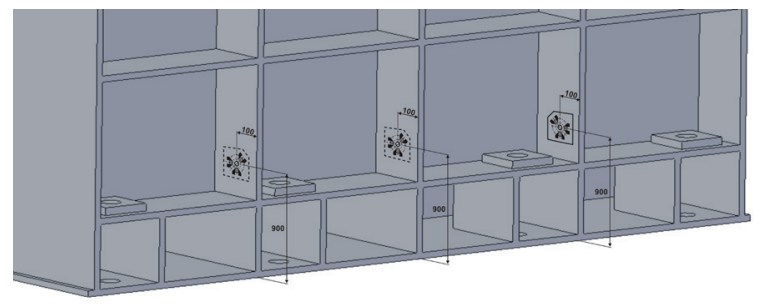

Fig. 9: Location of strain-gages for hole-drilling on outer vertical webs.

Equipment RS - 200 was used for the measurement. With respect to working conditions in location of measurement there were proposed procedure of drilling by hand electric drilling-machine connected by cardan joint (Fig. 10).

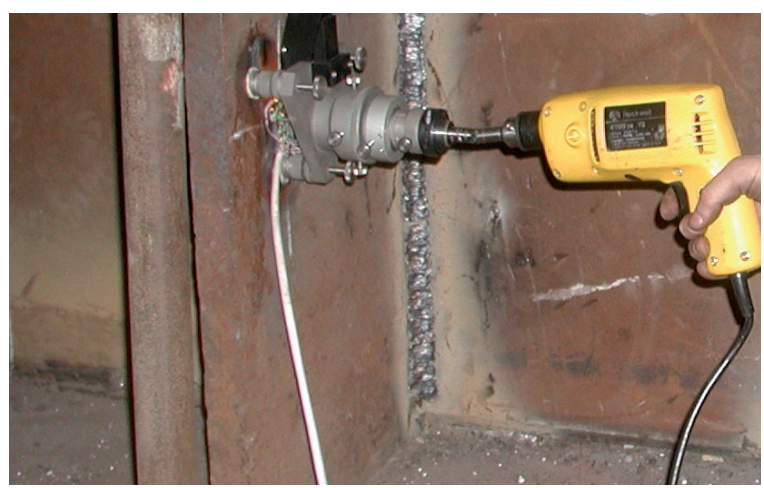

Fig. 10: Hole-drilling by systém RS 200.

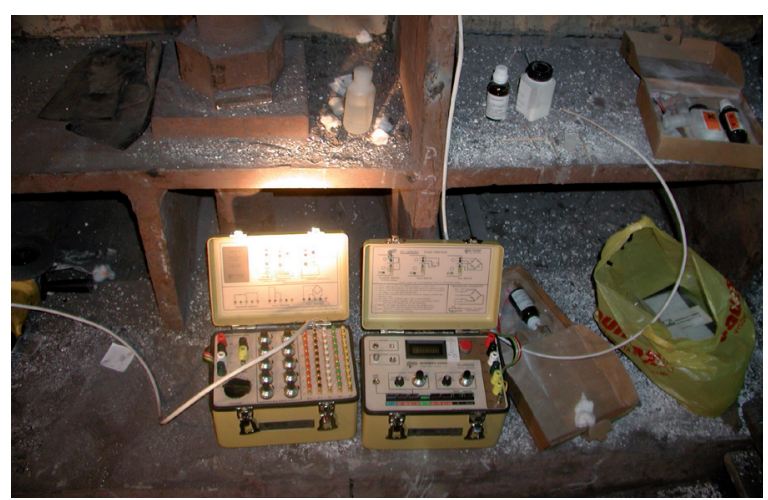

Fig. 11: Strain-gage apparatus P 3500 with switching box SB 10.
Data about radial deformation from three straingages in rosette were registered by strain-gage apparatus $P 3500$ and switch box SB 10 (Fig. 11) that after connecting to strain-gage rosette RY 21 and setting up coefficient of deformation sensitivity and balancing allowes gain strains for every incremental step of drilling.

During incremental drilling were registered magnitudes of strains that represents stresses from selfweight as well as residual stresses. Values for the middle rib are given in protocols about residual stresses. In Fig.12 is given an example of measured results gained from program MEZVYNA. Here is given also percentage of released deformations according to Standard ASTM E 837-01.

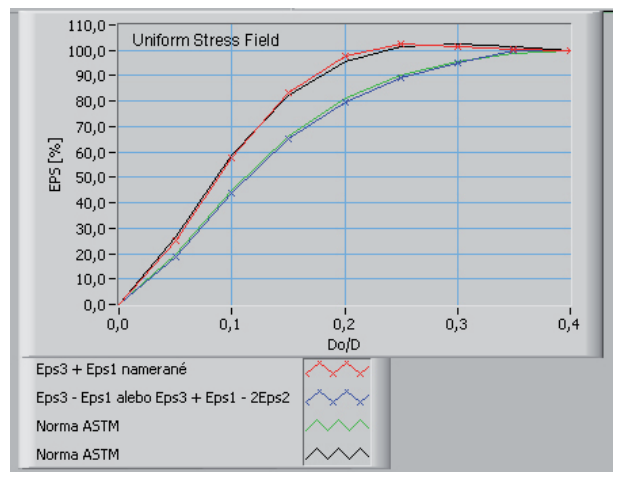

Fig. 12: Results of measurements according to ASTM method for middle rib determined by program MEZVYNA.

By the hole-drilling method can be confirmed values of stresses in pedestal resulting from self-weight of converter, brickwork, residuals of steel bath, pedestal, bearings and their houses. Of course, in these stresses are superimposed also magnitudes of residual stresses due to overloading or production technology and modifications of pedestal. The localization of places for the hole-drilling had taken into account a fact that influence of welds in the structure should be as small as possible.

\section{Directions and Magnitudes of Residual Stresses in Hot Rolled Steel Sheets}

The biggest task that was solved on our workplace was oriented to measurement of released residual stresses by the hole-drilling method according to Standard ASTM for two types of sheets produced by two different regimes of rolling (Trebuňa et al., 2005).

At the first part of solution was accomplished mea- 
surement and evaluation of magnitudes and directions of principal residual stresses on sheet specimens made from roll and from plane sheet. After realization of measurements on the specimens made by alternative technology of rolling there was realized detailed analysis of measured values representing magnitudes and directions of principal residual stresses in the locations where the interpretation and verification of results demonstrated noticeable qualitative and quantitative changes. Then in four such locations were performed additional analyses with altogether 20 measurements.

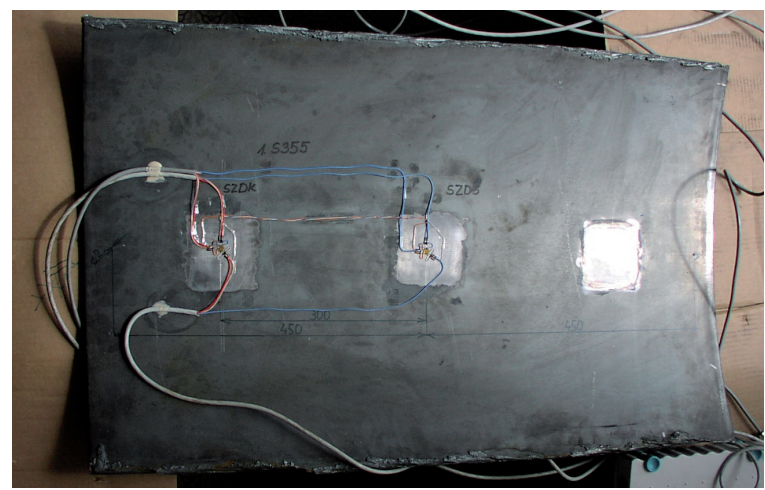

a)
On the basis of this experiment we were able reliable compare two technologies of steel sheet production.

The measurement and evaluation chain consists of a system for measurement of residual stresses SINT MTS 3000, strain-gage apparatus SPIDER 8, source of pressured air, reduction valve with a filter and computer with program product RESTAN and MEZVYNA.

In Fig. 13 are shown specimens of material produced by the first technology of rolling taken from a sheet roll (Fig. 13a) and from plane sheet (Fig. 13b).

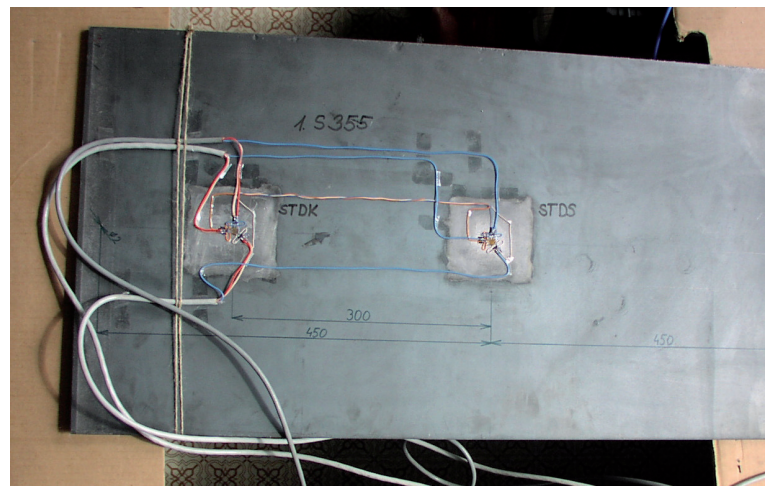

b)

Fig. 13: Specimen made by first technology of rolling a) from a roll, b) from a plane sheet.

Because it was found out by measurements that released deformations depending on the ratio of drilled hole depth and middle diameter of strain-gage rosette were not in normalized area (according to ASTM E 83701), it was performed evaluation of stresses by additional three method that allow determination of stresses in blind hole and non-regular distribution of stresses along drilled hole:

- integral method,

- Kockelmann method,

- method of power series.

Evaluation of measured data was accomplished by programs Restan and MEZVYNA.

The most important result of measurements were those determined by Standard ASTM E-837-01 (Fig. 14). From the charts of principal stresses along the hole that are part of addendum of report (Trebuña et al., 2005) result that all computational procedures confirm non-regular stress distribution along drilled hole. By integral and Kockelmann method can be the stresses determined only near to object surface and for power series method they can be assessed also for bigger depth of hole.

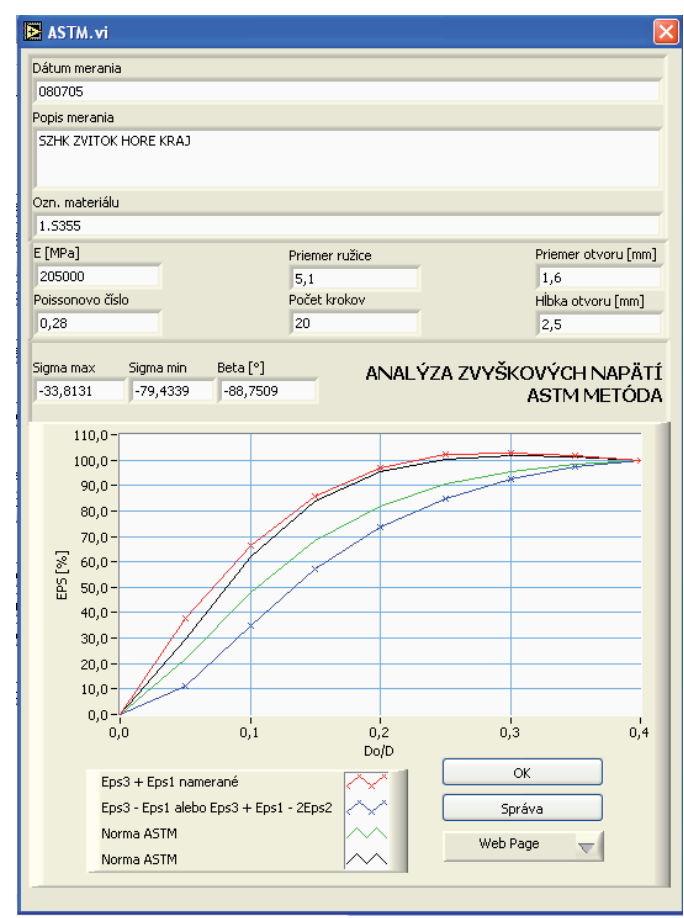

Fig. 14: Processing of measured data according to Standard ASTM in program MEZVYNA. 


\section{Conclusion}

Almost all technological processes (machining, grinding, forming, welding) induce the residual stresses in produced machine parts. It is a reason why such stresses are sometime called as technological. Knowledge of residual stresses is important for accurate determination of fatigue lifespan or for hardening of part. Residual stresses can have negative, but also positive effect. Residual stresses created during technological operations can increase level of stresses and accordingly contribute to opening of micro cracks. They have positive influence in the case of creation of residual stresses of pressure character that can sometimes substantially increase fatigue lifespan and prolong lifetime of structure. Removing of residual stresses can be very expensive and sometimes is much more easy to assess their influence to lifetime of element. In most cases it is not easy to determine residual stresses analytically.

Accordingly, the experimental methods of residual stress determination are always very important and we created our own program for their evaluation by the hole-drilling method. The program was used in solving various projects solved on our workplace and here were described only some.

\section{Acknowledge}

This contribution is the result of the project implementation "Center for research of control of technical, environmental and human risks for permanent development of production and products in mechanical engineering" ITMS:26220120060, supported by the Research \& Development Operational Programme funded by the ERDF.

\section{References}

ASTM Standard E837-01, norma USA pre meranie zvyškových napätí

Šarga, P.: Riadenie odvŕtavania a vyhodnocovania zvyškových napätí, DDP TU v Košiciach, September 2005

Trebuňa, F. a kolektív: Expertíza tabúl' provizórneho hradenia vtokov tg1 a tg2 vo ve Ružín I, Košice, 2004

Trebuňa, F. a kolektív: Kmitanie stojana konvertora, Košice, 2005

Trebuňa, F. a kolektív: Smery a vel'kosti zvyškových napätí konštrukčných za tepla valcovaných plechov, Košice, 2005

Trebuňa, F. a kolektív: Určenie zvyškovej životnosti potrubných dvorov, Košice, 2004

Trebuňa, F., Šimčák, F.: Kvantifikácia zvyškových napätí tenzometrickými metódami. Grafotlač, Prešov, 2005. 134 str., ISBN 808073-227-2

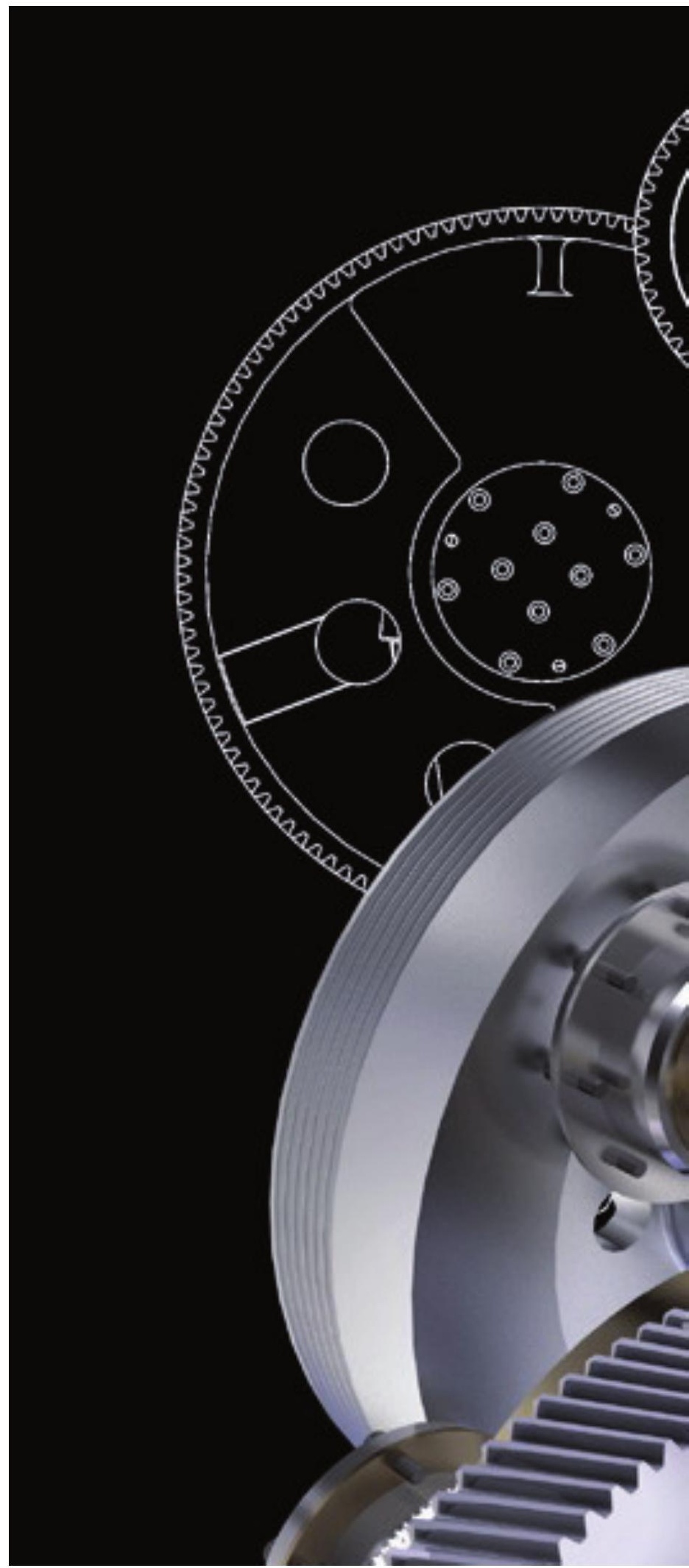

